Does the church deliver? Perceptions amongst South Africans about the role of the church in the HIV/AIDS field

P J van Dyk \& A C van Dyk

(University of South Africa)

\title{
ABSTRACT
}

\section{Does the church deliver? Perceptions amongst South Africans about the role of the church in the HIV/AIDS field}

The aim of this study was to investigate the perceptions of South Africans regarding the church and their attitudes towards HIVpositive people and condom usage. A semi-structured questionnaire was used to investigate participants' perceptions and attitudes towards the church, HIV-positive people and condom usage. The questionnaire was completed by 1352 participants from diverse religious and other backgrounds. Results showed that $67.2 \%$ of participants (mostly active church goers) were prepared to go to their minister for support (if they were HIV-positive). Views that HIV/AIDS is God's punishment, that HIV-infection is the result of a 'sinful lifestyle' and the condemnation of condom usage were more prevalent among certain categories of people (eg. those who had not been tested for HIV before, men, persons from rural areas, people of lower education level, the unemployed and in some cases the more active members of the church). A third (33.5\%) of the participants believed that religious people would be less prone to HIV-infection than non-religious people. 59.1\% participants (mostly women and active church goers) believed that the church is doing its best to support HIV-positive people.

\section{INTRODUCTION AND AIM}

HIV/AIDS poses a serious challenge to Sub-Saharan Africa and especially Southern Africa. The UNAIDS declared in 2006 that 'South Africa's AIDS epidemic - one of the worst in the world shows no evidence of a decline'. An estimated 5.5 million [4.9 million - 6.1 million] people were living with HIV in South Africa in 2005, including 240000 [93 000-500 000] children younger than 15 years (UNAIDS 2006). HIV/AIDS is increasingly disrupting the South African community and is therefore not only a medical problem, but also a social problem, which involves inter alia the church. 
With a growing number of HIV-positive members it is inevitable that the church will play an increasingly active role in addressing the HIV/AIDS problem in its midst (Anderson \& Rüppell 1999; Makuka \& Slonim-Nevo 2006). People living with HIV/AIDS (and their loved one's) need spiritual guidance and support. Often spiritual and religious beliefs play an important role in end-of-life decisions (Siegel \& Schrimshaw 2002), and may also help in structuring a person's life in a more positive way. Perceived positive effects of religious beliefs may include the following: comforting, emotional strengthening, social support, help to accept the illness, positive effects on health, reducing self-blame, the facilitation of self-acceptance, and the relieve of fear and uncertainty about death (Siegel \& Schrimshaw 2002). HIV-positive persons may also feel comforted by their beliefs in a forgiving God and the question if HIV infection should be regarded as God's punishment for sin is often foremost in their minds (Kaldjian, Jekel \& Friedland 1998; Van Dyk 2005).

Unfortunately the church has in the past not only played a positive role in the HIV/AIDS field. Its attitudes and actions are often perceived by HIV-positive and other people (including members of the church) as either indifferent (Black 1997), opposing those who are working in the HIV/AIDS field (Hartwig, Kissioki \& Hartwig 2006), or as negative. Such negative attitudes often include the view that AIDS is the result of aberrant or immoral behaviour. This may then result in discriminative practices against HIV-positive people, because they are perceived as individuals who had "stepped out of line of 'normal' sexual morality" (Campbell, Yugi \& Maimane 2006; Black 1997). Research has further shown that churches and faith-based organisations often not only foster HIV stigma, but also mitigate it (Hartwig et al 2006).

In the light of the above scenario, it is clear that the church and faith-based organisations can potentially play an important role in the HIV/AIDS field, but that negative perceptions about the church may severely hamper their effectiveness in this field (Van Arkel 1991). The aim of this study was to investigate perceptions of South Africans about the church and its role within the HIV/AIDS field. The survey focussed on issues such as trust, ability and willingness of the church to support HIV-positive persons, the church's perceived attitude and theological views with regard to HIV/AIDS and related issues such as condom usage. 


\section{METHOD}

Students, who were enrolled for an HIV/AIDS care and counselling course at the University of South Africa (UNISA) in 2004, were used as voluntary field workers to collect data for this study. Each fieldworker was asked to randomly select at least two subjects from his or her community to complete a questionnaire. Students were specifically requested NOT to fill in the questionnaires themselves and the principles of randomness were explained to them in the instruction booklet. To ensure anonymity, subjects were instructed to place their completed questionnaires in an envelope and to seal it before handing it to the fieldworker/student, who posted it to the university as part of their assignments.

The advantage of using UNISA students as field workers, was the variance of subjects who could be reached with the questionnaires: UNISA is a distance education university, with students residing throughout South Africa. The sample therefore included urban as well as rural inhabitants of all nine provinces in the country. The sample is, however, not necessarily representative of all South Africans, and should rather be seen as a 'convenience sample' that tried to avoid any bias in terms of religion, gender, age, ethnic group, occupation, educational level, or geographic location (see details in Table 1). A total of 1352 participants completed and sent in their questionnaires.

\subsection{Measuring instrument}

A semi-structured questionnaire was used to obtain the following information from the participants:

- Biographical information (age, sex, residence, ethnic group, academic qualifications and occupation).

- Religious affiliation and level of involvement in their church or religious institution.

- HIV-related information about the participant (i.e. if the subject has previously been tested for HIV and what his or her HIV status is).

- Preparedness to go to their minister or priest for help and support if the subject was HIV positive (or may become HIV positive in future). Reasons for his or her willingness or unwillingness to go to the church for guidance and support. 
- Preparedness to go to members of their congregation for help and support, if HIV-positive (or if the person was to become HIV positive). Reasons for willingness or unwillingness to go.

- Likert scales (ordinal 5-point scales, ranging from 'strongly agree' to 'strongly disagree') were used to measure participants' opinions and attitudes in terms of the following:

- Is the church doing enough to support HIV-positive people in South Africa?

- Is AIDS God's punishment for sin?

- Should the church condemn the 'sinful lifestyle' of HIVpositive people?

- Should the church condemn the use of condoms because it may encourage promiscuity?

- Will strongly religious people be less prone to HIVinfection than non-religious people?

- How supportive is their own church or congregation towards HIV-positive people? In an open question, participants were also asked to explain exactly what their church is doing to support people living with AIDS.

\subsection{Statistical analysis}

The closed questions were coded and analysed, using the Statistical Package for the Social Sciences (SPSS). Descriptive, inferential and correlational statistical techniques were used to analyse the data. The level of significance was set at 5\%. Non-parametric tests (eg. MannWhitney $U$, Kruskal-Wallis analysis of variance) were used with attitude scales, because these scales are non-standardised ordinal scales (Coolican 2004). Chi-square tests for categorical variables were used, as well as Spearman's correlations for ordinal data. The open-ended questions were analysed by using the method of content analysis.

\section{RESULTS}

\subsection{Demographic features of participants}

The mean age of the participants was 33.2 years $(S D=11.04$ years; range $=10$ to 70 years) and the majority of the participants were black $(74.2 \%)$, female $(63.5 \%)$, resided in cities $(51.2 \%)$, and had a postschool qualification (51.5\%). Participants' occupations were varied 
and included categories such as education (19.2\%), medical or nursing professions $(12.1 \%)$, economy or commerce $(11.2 \%)$ and social work $(4.9 \%)$, while $14.5 \%$ of the participants were unemployed.

Various religious affiliations were represented such as Protestantism (35.4\%), Pentecostal (19.6\%), Roman Catholic (12.5\%), African Initiated Churches \& African traditional religion (11.1\%), and other churches and religions (19.3\%). (See Table 1 for more detailed information.)

On the question how active or involved they were in their churches, $24.1 \%$ of the participants said that they were 'very active'; $32.4 \%$ said that they were 'active'; $30.6 \%$ were only 'occasionally active' while $12.8 \%$ were rarely involved in church activities.

More than half of the participants $(57.2 \%)$ were previously tested for HIV. Eighty six of the participants $(6.5 \%)$ indicated that they were HIV positive (representing $11.24 \%$ of those who were previously tested); $52.3 \%$ were HIV negative; $36.6 \%$ did not know their status, and $4.7 \%$ preferred not to disclose their HIV status in the questionnaire.

\subsection{Preparedness to ask support from their minister or priest, if HIV positive}

The majority of participants in the study $(67.2 \%)$ were willing to go to their minister or priest for support, if they were to be HIVpositive, while $15.1 \%$ were unsure and $17.7 \%$ said that they would definitely NOT go to the minister for support. Significantly more Coloureds $(84.6 \%$ or $66 / 78)$ and Blacks $(82.06 \% ; 700 / 853)$ were prepared to go to their minister or priest if they were infected with HIV, than Asians $(67.4 \% ; 31 / 48)$ or Whites $(64 \% ; 99 / 153),\left(\chi^{2}=\right.$ $31.056 ; \mathrm{df}=4 ; \mathrm{p}<.001)$. Although not significant on the .05 level, there was a tendency for participants who were HIV-positive to be less willing to go to their ministers or priests for support $(73.3 \%$; $55 / 75)$ than participants who were HIV-negative $(82.3 \%$; 493/599), $\left(\chi^{2}=3.529 ; \mathrm{df}=1 ; \mathrm{p}=.060\right)$.

Participants who indicated that they were actively involved in their congregations, were significantly more willing to go to their ministers for support (should they be HIV positive) (88.5\%; $602 / 680$ ) than participants who were rarely involved in their congregations $(65.7 \% ; 289 / 440),\left(\chi^{2}=85.733 ; \mathrm{df}=1 ; \mathrm{p}<.001\right)$. Only 
$32.1 \%(9 / 28)$ of the participants, who did not belong to any church, said that they would go to a minister of faith for support, should they test HIV positive.

The reasons given by participants why they would go to their ministers or priests (if they tested HIV positive) were as follows: $45.9 \%$ believed that the minister will support and accept them; $37.2 \%$ thought they would need religious guidance; $33.9 \%$ believed that the minister will honour the confidentiality of their consultations; $29.4 \%$ thought they can trust their minister; and 26.3\% believed that their minister would be able to help them. Participants who indicated that they would not go to their minister for support or help (if they tested HIV positive) gave the following reasons: they will be too ashamed (21\%); they don't think that the minister will be able to help them $(19.7 \%)$; or they believed that the minister will condemn and reject them (10.4\%).

\subsection{Preparedness to access support from members of the congregation or religious community if HIV positive}

Participants were less prepared to go to members of their congregation for help (should they test HIV positive). Although $52.2 \%$ said that they would access help from members of their religious communities, $18.7 \%$ were not sure, and $29.1 \%$ said that they would definitely NOT go to members of their congregation for support or help.

Those willing to access support and help from members of their religious community, gave the following reasons: $41.1 \%$ believed that they will be accepted; $22.1 \%$ believed that members will be able to support and help them; $20.9 \%$ believed that their status would be kept a secret, and $18.6 \%$ said that they trusted the members of their congregation enough to ask for support.

Those who indicated that they would definitely NOT go to members of their congregation for support, gave the following reasons: $28.4 \%$ believed that members of their congregation will not keep their positive status a secret; $18.7 \%$ did not trust them enough; $17.5 \%$ did not think congregation members will be able to help them; $14.5 \%$ believed that members will condemn and reject them; and $13.8 \%$ said that they would feel too ashamed to share their status with members of the congregation. 


\subsection{Is the church doing enough to support HIV-positive people in South Africa?}

More than half of the participants (59.1\%) believed that the church was doing its best to support HIV-positive people in South Africa, while $20.5 \%$ believed that the church was definitely NOT doing enough. Another $20.5 \%$ said that they didn't know if the church was doing enough or not.

The results of analysis of variance, indicated that participants who believed that the church is doing its best to support HIV positive people, were significantly more likely to be:

- women than men $(U=190948, p=.018)$;

- willing to go to their minister for help (should they become infected $)(U=59064, p<.001)$;

- prepared to go to the religious community for help and support $(U=82941, p<.001)$;

- actively involved in church activities $(U=157207, p<.001)$;

- living in rural areas rather than cities or towns $(\mathrm{H}(2)=11.785$, $\mathrm{p}=.003)$; and

- black rather than the any other ethnic group $(\mathrm{H}(4)=44.701$, $\mathrm{p}<.001)$.

\subsection{Is Aids God's punishment for sin?}

Only $16.7 \%$ of the participants believed that AIDS is God's punishment for sin, while $14.3 \%$ were not sure and $69 \%$ disagreed with the statement. Participants who believed that AIDS is God's punishment for sin, were significantly more likely to be:

- those who were not previously tested for HIV $(U=188055.50$, $p<.001)$;

- Black people $(\mathrm{H}(4)=19.200, p=.001)$;

- people living in rural areas $(\mathrm{H}(2)=23.361, \mathrm{p}<.001)$;

- participants who did not have matric $(\mathrm{H}(2)=13.353, \mathrm{p}<.001)$; and

- participants who were unemployed $(\mathrm{H}(7)=26.549, \mathrm{p}<.001)$.

Younger people were also significantly more inclined than older people to believe that AIDS is Gods punishment for $\sin \left(r_{s}=.129, p\right.$ 
$<0.001$, two-tailed). It should, however, be noted that although significant, the correlation is small.

\subsection{Should the church condemn the 'sinful lifestyle' of HIV- positive people?}

More than $20 \%(21.5 \%)$ of the participants believed that the church should condemn the 'sinful lifestyle' of HIV-positive people, while $66.1 \%$ disagreed with the statement, and $12.4 \%$ were not sure. Participants who believed that the church should condemn the socalled 'sinful lifestyle' of HIV-positive people were significantly more:

- active members of the church $(U=188132.50, p=.012)$;

- inhabitants of rural areas $(\mathrm{H}(2)=13.632, \mathrm{p}=.001)$;

- participants who did not have matric $(\mathrm{H}(2)=13.353, \mathrm{p}=.001)$;

- unemployed $(\mathrm{H}(7)=15.183, \mathrm{p}=.034)$; and

- $\operatorname{men}(U=181040, p=.005)$.

Participants who believed that AIDS is God's punishment for sin, also tended to believe that the church should condemn the 'sinful lifestyle' of HIV-positive people $\left(\mathrm{r}_{\mathrm{s}}=.325, \mathrm{p}<0.001\right.$, two-tailed).

\subsection{Should the church condemn the use of condoms because it may encourage promiscuity?}

Almost a third of the participants (30.5\%) believed that the church should condemn the use of condoms because it encourages promiscuity. The majority $(60.4 \%)$ believed, however, that the church should NOT condemn condoms, while 9.1\% were unsure. Participants who believed that condoms should be condemned by the church were those who

- were NOT themselves tested for HIV before $(U=184572.00$, $p=.001)$;

- were very active in their churches $(U=163704.50, p<.001)$;

- were prepared to go to their minister for HIV support $(U=$ $72929.00, p<.001)$;

- were willing to go to members of their religious community for HIV support $(U=107332.50, p<.001)$;

- were living in rural areas, rather than in towns $(\mathrm{H}(2)=8.910, \mathrm{p}$ $=.012$ ); 
- were Asians $(\mathrm{H}(4)=30.966, \mathrm{p}<.001)$;

- $\operatorname{did}$ not have matric $(\mathrm{H}(2)=16.837, \mathrm{p}<.001)$; and

- belonged to a Pentecostal/Apostolic church rather than to one of the other Protestant churches $(U=45331, \mathrm{p}<.001)$ or to the Catholic church $(U=18216, \mathrm{p}=.031)$. There was no significant difference between members of the Catholic Church and Protestant Churches with regard to their evaluation of condoms $(U=33449, \mathrm{p}=.069)$.

There were also significant differences in the beliefs regarding condoms among participants in different occupations: Social workers, religious workers and educators generally believed that the church should condemn condoms, while participants working in the medical and nursing professionals strongly believed that the church should NOT condemn condoms $(\mathrm{H}(7)=27.10, \mathrm{p}<.001)$.

There were also significant correlations (all correlations are two-tailed) between the belief that the church should condemn condoms and the following views:

- the view that the church should condemn the 'sinful life' of HIV-positive people $\left(\mathrm{r}_{\mathrm{s}}=.275, \mathrm{p}<0.001\right)$;

- the perspective that AIDS is God's punishment for $\sin \left(\mathrm{r}_{\mathrm{s}}=\right.$ $.306, \mathrm{p}<0.001)$; and

- the belief that strongly religious people will be less prone to HIV infection than non-religious people $\left(\mathrm{r}_{\mathrm{s}}=.376, \mathrm{p}<0.001\right)$.

\subsection{Will strongly religious people be less prone to $\mathrm{HIV}$-infection than non-religious people?}

A third (33.5\%) of the participants believed that strongly religious people will be less prone to HIV-infection than non-religious people, while $55.5 \%$ disagreed with the statement and $11 \%$ were not sure. The following groups were significantly more inclined to believe that religious people will be less prone to HIV-infection:

- $\operatorname{Men}(U=180482.00, p=.002)$;

- Participants who were very active in their church $(U=$ 173361.00, $p<.001)$;

- Rural participants $(\mathrm{H}(2)=12.65, \mathrm{p}=.002)$;

- Black people $(\mathrm{H}(4)=10.332, \mathrm{p}=.035)$; 
- Participants who were prepared to go to their minister for HIV counselling $(U=82981.50, p<.001)$; and

- Participants who were prepared to go to the members of their congregation for HIV support $(U=113894.50, p=.001)$.

There were significant correlations (two-tailed) between the belief that non-religious people will be more prone to HIV infection and the following two beliefs:

- The view that the church should condemn the 'sinful lifestyles' of HIV positive people $\left(\mathrm{r}_{\mathrm{s}}=.241, \mathrm{p}<0.001\right)$;

- The belief that AIDS is God's punishment for $\sin \left(r_{s}=.297, p\right.$ $<0.001)$.

\subsection{The role of the church in supporting HIV positive people}

More than half of the participants (55.9\%) said that their church or congregation was supportive to HIV positive people, while $11.8 \%$ said that their church was definitely NOT supportive. A further $25.4 \%$ had no idea what their church was doing.

Content analysis revealed both positive and negative evaluations from the participants regarding the church's role and contribution in the HIV/AIDS field. The following are examples of some of the negative remarks regarding the church's involvement:

\section{Negative evaluation:}

- 'My church only preaches abstinence'.

- 'They prefer to ignore AIDS and do nothing'.

- 'My church does not talk about AIDS at all'.

- 'The church doesn't want to become involved'.

- 'All they do is pray'.

- 'They use it as an excuse that people won't come forward and say that they are HIV positive - therefore they do nothing'.

It is clear from the above comments that criticism against the church primarily focussed on its unwillingness to become involved in the HIV/AIDS field, or alternatively that the church limited its involvement to prayer and talk only.

In contrast to the above criticisms, participants gave examples of the church's positive involvement and contributions in various fields with regard to HIV/AIDS. 


\section{Positive involvement}

Prevention and awareness:

- Prevention and AIDS awareness days (workshops, motivational speakers, handing out condoms - always with abstinence messages, print reading material (eg. with latest research).

- Youth outreach projects (plays, poetry, occasions for youth to meet and talk about HIV).

- Candle lighting ceremonies.

- Active AIDS task teams.

Medical and physical care:

- Home-based care (visit the sick, help with home chores such as cleaning and cooking, taking care of sick people [eg. bathing, feeding], reading to sick people, palliative care for the terminally ill).

- Subsistence support (money, social grants, clothes, blankets, food, shelter, transport to hospitals, temporary shelters, soup and bread kitchens).

- Self-help programmes (assist HIV positive people to find work; help families to start vegetable gardens for healthy food).

- Orphan care (money specifically for orphans and children's hospitals, food packages and gifts for orphans, sponsor formula milk for babies, "feed 33 children $3 X$ week", and support children with ART, offer shelter for orphans, adoption schemes).

- Medical care (provide nutritional supplements, money for antiretrovirals).

- Building a hospice, donate to funeral costs, food hampers on a monthly basis.

- Support groups consisting of nurses, doctors, social workers and counsellors in the congregation.

- 'Daily R1 for life donations for care organisations'.

Counselling and spiritual care

- Spiritual care (prayers, bereavement counselling). 
- Support for HIV positive people (help or care desk, HIV task teams, counselling services, taking them to recreational centres).

- Encouragement to be tested and to disclose status.

- Phone-in help line.

- Women groups to visit hospitals, sick homes, care for children. Training

- Training of ministers and members as AIDS counsellors (with church sponsored bursaries), and providing debriefing for counsellors and home-based caregivers.

- Domestic worker training.

The above examples clearly illustrate the fact that many churches and congregations are actively involved in all aspects of the HIV/AIDS field and that many of their contributions are long-term and involve both spiritual counselling and physical support. Many churches are also very involved in prevention and awareness programmes.

\section{DISCUSSION AND CONCLUSIONS}

It is important that churches in South Africa should pay increasing attention to the HIV/AIDS problem in their midst. To be able to this they will have to first address the negative perception which still persists among many South Africans (20\% of participants) that the church is not pulling its weight in the HIV/AIDS field and/or were unwilling to go to their minister or priest $(17.7 \%)$ or to their congregation $(29.1 \%)$ for help and support if they were to become HIV positive. Perceptions that the church will condemn HIV-positive people, or at least see them in a negative light, that ministers/priests or members of the congregation will not keep their status confidential, or that the church would either not be able or willing to support them probably persist among a sizeable proportion of South Africans. If these negative perceptions cannot effectively be addressed by the church it will remain an important barrier in preventing people, affected by HIV/AIDS, from coming to the church for spiritual guidance and other support.

To change negative perceptions and attitudes is not always easy. It is therefore necessary that the church's positive involvement in the HIV/AIDS field should continuously be 'advertised' by words 
and deeds. Positive and unbiased reference to church projects, regular sermons to address theological issues such as: negative and sanctimonious attitudes, the complex relationship between sin and suffering (eg. illness) and the Christian values of loving-care and acceptance. HIV/AIDS should therefore continuously be part of the church's activities and not only be addressed occasionally or reluctantly.

The results of this study have further emphasised the fact that negative attitudes towards HIV-positive people and condom usage often exist among religious workers and members of the congregation who are most active in the church. Negative attitudes are also most often associated with people of lower educational levels, rural people, black members and men. The church should acknowledge these tendencies and focus their attention on these identified target groups for changing negative attitudes. Training programmes in cultural diversity, sensitivity to and acceptance of HIV-positive people and the nature and function of negative attitudes can probably help to change such attitudes.

The research has, however, also shown that many churches and congregations are already actively and positively involved in the HIV/AIDS field. These activities range from awareness and prevention programmes to counselling and physical and spiritual care programmes. These examples should motivate churches and congregations (not yet involved) to become increasingly involved in the HIV/AIDS field. Failure to do so may result in one of the biggest failures of the church in human history! 
Table 1 Descriptive statistics for research participants $(\mathrm{N}=1319-1352)$

1.1 AGE

$<25$ years

26 - 35 years

$36-45$ years

46 - 55 years

$>55$ years
N

336

474

345

147

41

493

859

Male

Female

1.3 ETHNIC GROUP

Black

White

Coloured

Asian

Other
1003

189

92

59

7
$\%$

25.0

35.3

25.7

10.9

3.1

36.5

63.5

74.3

14.0

6.8

4.4

.5

\subsection{AREA OF RESIDENCE}

City

Town

Rural

1.5 ACADEMIC QUALIFICATION

No School

Grade $1-5$

Grade 6 - 9

53

4.0

Grade $10-11$

166

12.5

Grade 12

Post school qualification

685

51.5

\subsection{OCCUPATION}

Education 253

19.2

Medical/nursing

Social work / Religious workers

Administrative

Financial

Commercial

Trade / Technical

Scholar / Student

Unskilled / Domestic worker

\subsection{RELIGIOUS AFFILIATION}

Protestant 


\begin{tabular}{|lcc|}
\hline Lutheran & 91 & 6.9 \\
Anglican/Methodist/Presbyterian & 290 & 21.8 \\
Dutch Reform & 89 & 6.7 \\
\hline
\end{tabular}

$\begin{array}{lll}\text { Roman Catholic } & 166 & 12.5 \\ \text { Apostolic/Pentecostal } & 260 & 19.6\end{array}$

African Initiated Churches

\& Traditional $\quad 142 \quad 11.1$

\begin{tabular}{|lcc|}
\hline ZCC and other & 118 & 8.9 \\
Traditional African Religion & 24 & 1.8 \\
\hline
\end{tabular}

Other churches and religions $256 \quad 19.3$

\begin{tabular}{|lrc|}
\hline Muslim & 25 & 1.9 \\
Hindu & 23 & 1.7 \\
Buddhist & 3 & .2 \\
Other churches & 205 & 15.4 \\
\hline
\end{tabular}

No religious affiliation

34

2.6

\section{Consulted literature}

Anderson, K \& Rüppell, G 1999. Facing AIDS: education in the context of vulnerability to HIV/AIDS. Geneva: World Council of Churches.

Black, B 1997. HIV/AIDS and the church: Kenyan religious leaders become partners in prevention. Aidscaptions 4(1), 23-26.

Campbell, C, Yugi, N \& Maimane, S 2006. AIDS stigma, sexual moralities and the policing of women and youth in South Africa. Feminist Review 83, 132138.

Coolican, H 2004. Research methods and statistics in psychology, $4^{\text {th }}$ ed. London: Hodder Arnold.

Hartwig, K A, Kissioki, S \& Hartwig, C D 2006. Church leaders confront HIV/AIDS and stigma: a case study from Tanzania. Journal of Community \& Applied Psychology 16(6), 492-497.

Kaldjian, L C, Jekel, J F \& Friedland, G 1998. End-of-life decisions in HIVpositive patients: the role of spiritual beliefs. AIDS 12(1), 103-107.

Makuka, L \& Slonim-Nevo, V 2006. The role of the church in the fight against HIV/AIDS infection in Zambia. International Social Work 49(5), 641-649.

Siegel, K \& Schrimshaw, E W 2002. The perceived benefits of religious and spiritual coping among older adults living with HIV/AIDS. Journal for the Scientific Study of Religion 41(1), 91-102. 
United Nations Programme on HIV/AIDS July 2006. Report on the global HIV/AIDS epidemic. Geneva, Joint United Nations Programme on HIV/AIDS

Van Arkel, J De J 1991. Living in an AIDS culture. Pretoria: University of South Africa.

Van Dyk, P J 2005. Bereavement and spiritual counselling, in: van Dyk, A C (ed). HIV/AIDS care and counselling, $3^{\text {rd }}$ ed, 236-256. Cape Town: Pearson Education. 